\title{
Histopathological findings and immunohistochemical staining of Neospora caninum infection in placentas of animals for slaughter
}

\section{Achados histopatológicos e marcação imuno-histoquímica da infecção por Neospora caninum em placentas de animais destinados ao abate}

\author{
Allana Freitas Barros ${ }^{1}$; Higor Ferreira Silva ${ }^{1}$; Renata Mondêgo de Oliveira ${ }^{2}$; \\ Nathálya dos Santos Martins²; Mylena Andréa Oliveira Torres ${ }^{3}$; Fábio Henrique \\ Evangelista de Andrade ${ }^{4}$; Tatiane Aranha da Penha ${ }^{4}$; Alessandra Lima Rocha ${ }^{4}$; \\ Solange de Araujo Melo ${ }^{4}$; Ana Lucia Abreu-Silva ${ }^{4 *}$
}

\begin{abstract}
Bovine neosporosis is a parasitic disease caused by the protozoan Neospora caninum, which is one of the main pathogens that cause abortions in cattle worldwide. It is responsible for large losses in dairy and beef cattle, especially with regard to the expenses associated with decreased productivity and increased discard. In the State of Maranhão, the occurrence of this parasite has already been confirmed in the dairy cattle of three microregions that make up the state's dairy industry and in small ruminants of the municipalities of Amarante do Maranhão and Buritirana. This fact justifies the importance of determining the presence of $N$. caninum in cattle slaughtered in the slaughterhouses of the Island of São Luís, to help control the parasitic cycle in the cattle production system of the region under study, and the importance of its diagnosis. The objective of the research was to conduct a histopathological and immunohistochemical characterization of bovine placentas infected with $N$. caninum collected in slaughterhouses. Sixteen placenta samples from cows were randomly selected at the slaughterhouses of the city of São Luís for histological analysis and immunohistochemistry. Results showed that $31 \%$ of the placentas presented histopathological changes such as: inflammatory process, edema, hemorrhage and presence of hemosiderin. All slides with histopathological changes showed immunolabeling for $N$. caninum.
\end{abstract}

Key words: Slaughterhouse. Histopathological. Immunohistochemistry. Neosporosis. Placenta. Cows.

\section{Resumo}

A neosporose bovina é uma doença parasitária causada pelo protozoário Neospora caninum, que é um dos principais patógenos causadores de aborto em bovinos no mundo. É responsável por grandes prejuízos nos rebanhos de leite e de corte, principalmente no que se refere aos gastos associados à diminuição da produtividade e aumento do descarte. No estado do Maranhão, a ocorrência deste parasito

\footnotetext{
${ }^{1}$ Discentes de Mestrado em Ciência Animal, Universidade Estadual do Maranhão, UEMA, São Luís, MA, Brasil. E-mail: allana. barros@hotmail.com; trogir@hotmail.com

2 Discentes de Doutorado, Rede Nordeste Biotecnologia. Renorbio Ponto Focal Maranhão São Luís, MA, Brasil. E-mail: remondego@hotmail.com; veterinariamartins@hotmail.com

3 Prof ${ }^{a}$ Dr $^{\mathrm{a}}$, Universidade CEUMA. São Luís, Maranhão, Brasil. E-mail: mylena.torres@hotmail.com

4 Profs. Drs., Departamento de Patologia, Universidade Estadual do Maranhão, UEMA, São Luís, MA, Brasil. E-mail: hoibaf@ hotmail.com; tatianearanha@hotmail.com; alrvet@hotmail.com; sol-vet@hotmail.com; abreusilva.ana@gmail.com

* Author for correspondence
} 
já foi confirmada em rebanhos de bovinos de leite de três microrregiões que compõem a bacia leiteira do estado e em pequenos ruminantes dos municípios de Amarante do Maranhão e Buritirana. Justificando desta forma a importância de determinar a presença de $N$. caninum nos bovinos abatidos nos matadouros da Ilha de São Luís, para auxiliar no controle do ciclo parasitário no sistema de produção de bovinos na região em estudo e a importância do seu diagnóstico. O objetivo da pesquisa foi realizar a caracterização histopatológica e imuno-histoquímica de placentas bovinas infectadas por $N$. caninum coletadas em matadouro. Foram selecionadas ao acaso 16 amostras de placenta de vacas, provenientes de abatedouros do município de São Luís para análise histológica e imuno-histoquímica. Os resultados evidenciaram que $31 \%$ das placentas apresentaram alterações histopatológicas, tais como: processo inflamatório, edema, hemorragia e presença de hemossiderina. Todas as lâminas com alterações histopatológicas apresentaram imunomarcação para $N$. caninum.

Palavras-chave: Abatedouro. Histopatológico. Imuno-histoquímica. Neosporose. Placenta. Vacas.

Neosporosis is a disease caused by coccidia Neospora caninum, identified as one of the main causes of abortion in cattle and neuromuscular changes in dogs (GUIMARÃES, 2011; ALMERÍA, LOPEZ-GATIUS, 2013). In cattle, the main consequences of infection are related to estrus repetition, recurrent spontaneous abortions, and temporary anestrus. It is estimated that damage caused by the disease in the meat and dairy products industry worldwide is approximately US\$ 1 billion per year (REICHEL et al., 2013).

Bovines are one of the species most affected by $N$. caninum, and the main consequences are pathophysiological changes in the reproductive sphere. The infection may cause abortion in susceptible females, with or without fetal expulsion; term gestation with calf presenting clinical signs of the disease; or, in some cases, the calf may be apparently healthy, but infected and asymptomatic (MESQUITA et al., 2013). Abortion is a consequence of the mother's immune response to the parasite in placental tissue, leading to the activation of proinflammatory cytokines in response to protozoan multiplication associated with hormonal imbalance (DUBEY; SCHARES, 2006, 2011).

In the state of Maranhão, the occurrence of $N$. caninum was reported by Teixeira et al. (2010) in dairy cattle from three microregions of the Regional Dairy Industry, in which the prevalence of $50.74 \%$ of positivity was verified in sampled animals, confirming the presence of such an agent in our territory. $N$. caninum infection was also observed in goats and sheep in the municipalities of Amarante do Maranhão and Buritirana, which showed a prevalence of $4.35 \%$ and $4.69 \%$ respectively, according to the indirect immunofluorescence reaction technique (MORAES et al., 2011).

Histopathology was chosen among other direct diagnosis techniques, since it allows for the identification of specific lesions and infective forms and/or tissue cysts in the aborted material (WESTON, 2011); molecular techniques and immunohistochemistry are complementary tools that allow us to correlate parasite presence and tissue lesions observed, even in cases in which parasitism is not severe (MINEO, 2007). This work describes histopathological and immunohistochemical findings observed in bovine placentas infected with $N$. caninum collected at a slaughterhouse.

Sixteen bovine placenta samples were randomly collected at a slaughterhouse on the Island of São Luís, Maranhão. The samples were conditioned in flasks containing neutral buffered formalin for histological and immunohistochemical analysis.

Placental fragments were separated and processed in automatic histotechnology equipment following the routine technique for dehydration. Then, diaphanization and paraffin embedding were performed. After this procedure, paraffin blocks containing the fragments were sliced in a microtome at a thickness of between $4-5 \mu \mathrm{m}$. Sections were stained for histopathological examination using the 
Hematoxylin and eosin (HE) technique, as described by Tolosa et al. (2003).

Histological sections were submitted to an immunohistochemistry protocol using the biotin streptavidin-peroxidase method (Dako LSAB + Peroxidase Kit), following the protocol used by Benevides et al. (2012). We used a primary antibody (anti- N. caninum bovine serum, 1:99 diluted in BSA - bovine serum albumin), provided by the University of São Paulo. Slides were counterstained with Mayer's Hematoxylin.
Histological evaluation of placenta fragments showed tissue changes in five samples, which were inflammatory reactions, congestion, hemorrhage, and edema (Figure 1A and B). Hemosiderophages were found in previous hemorrhage areas. The lesions found corroborate Nematollahi et al. (2013), who have reported that vasculitis, severe congestion, perivascular mononuclear infiltration, vascular thrombosis, focal placentitis and foci of necrosis in cotyledons, are the most common findings in placentas of animals parasitized by $N$. caninum.

Figure 1. Histological sections of bovine placenta stained with H\&E. Normal tissue pattern in which villi can be observed A. 10x. Black arrows. B. 40x - Observe the areas of edema in the chorion laeve (yellow arrows) and the presence of mesenchymal cells (red arrows).

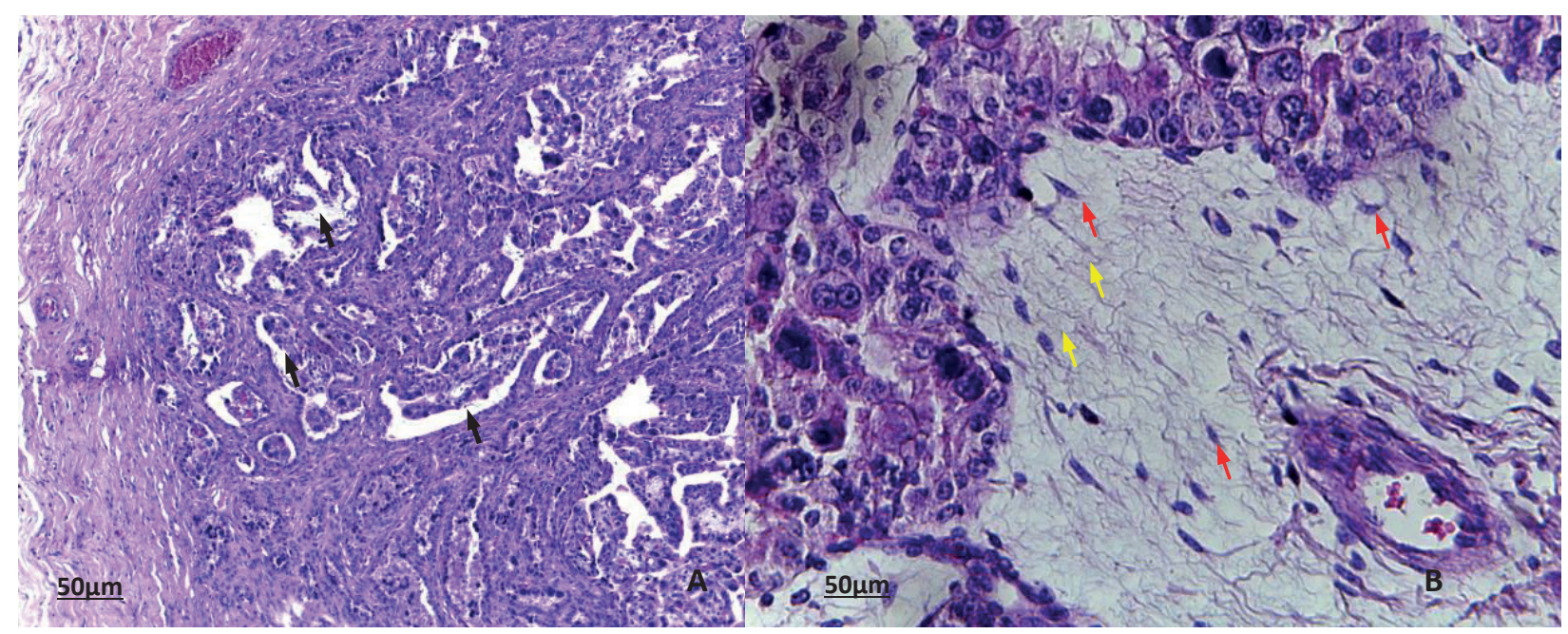

Congestion was one of the most frequent findings in the histopathological analysis of placental tissues tested positive for N. caninum. Congestion and the presence of fibrin in villi have been observed by Benevides et al. (2012) in placentas of cattle with 28 days of infection by $N$. caninum. These lesions are considered an indication of acute infections, suggesting a very recent exposure of the placenta to the parasite.

Hemorrhage was also a frequent finding in the analyzed samples; this lesion has also been described in abortions of sheep infected both experimentally (DUBEY, 2003) and naturally (PINTO et al., 2012) with $N$. caninum. Edema was found particularly in the chorion laeve and chorion frondosum, regions that presented greater immunolabeling. Pescador et al. (2007) observed the occurrence of edema in histopathological analyses of lung tissue from aborted fetuses tested positive for $N$. caninum. Edema is a histopathological finding of $N$. caninum infection, most frequently observed in cardiac tissue and the central nervous system (NEMATOLLAHI et al., 2013). 
The presence of hemosiderin in the histological analysis may be associated with the occurrence of hemorrhage since it consists of a progressive transformation of ruptured red blood cells, which liberate iron during their degradation process (KUMAR et al., 2013). Hemosiderin is the degraded and insoluble form of ferritin, which is observed when the total amount of iron in the organism is higher than what can be held by the ferritin storage, and can be viewed microscopically as a cluster within cells (HALLIDAY et al., 1994; GROTTO, 2008; CHIATTONI, 2016).
Mineo (2007) observed the replication of the parasite in the nervous system, heart, spleen, lungs, and skeletal muscles, as well as the membrane of the allantoic cavity of embryonated eggs infected with $N$. caninum, confirmed as positive through the Immunohistochemistry technique.

The five samples that showed histopathological lesions in immunohistochemical analysis displayed labeling for tachyzoite aggregates, an infecting form of $N$. caninum, in the placental tissue (Figure 2A, B, C). Tachyzoite labeling was also described by Mesquita et al. (2013) in the placental tissue of naturally infected goats.

Figure 2. Histological sections of bovine placenta labeled through immunohistochemistry. A. 40x. B. and C. 40x - Observe the labeling of Neospora caninum tachyzoites (arrows), aggregates of tachyzoites of the parasite labeled through the streptavidin-biotin-peroxidase immunohistochemical technique (reddish circle).
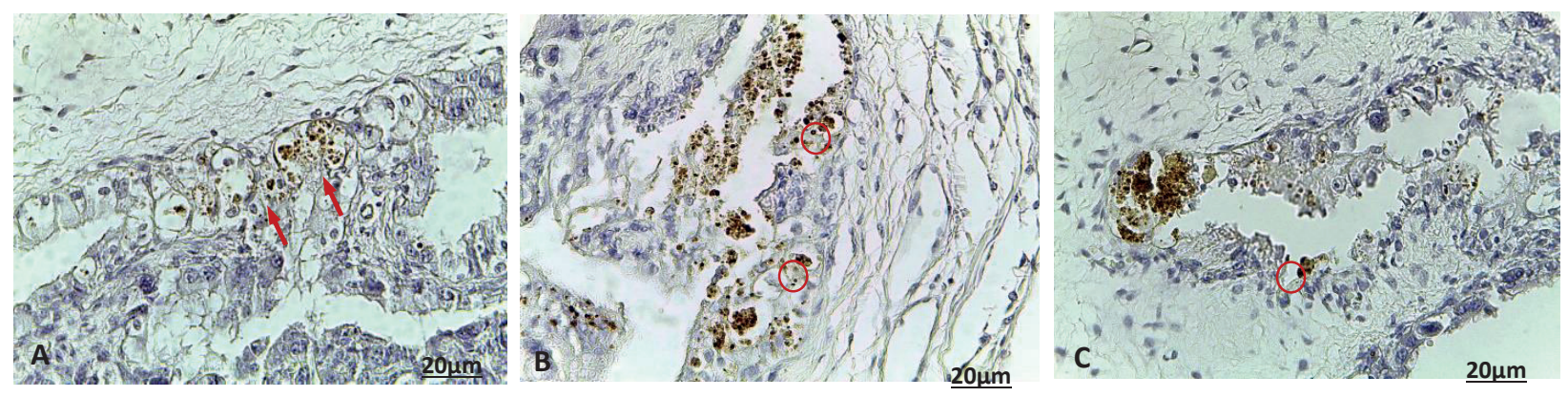

The absence of positive results in the other fragments analyzed does not rule out the possibility of parasite presence. According to Pinto et al. (2012), the absence of tachyzoites or cysts of $N$. caninum in tissues with lesions that are typical of this protozoan may occur due to its sporadic and sparse distribution within tissues.

The limitation of immunohistochemistry for confirmatory diagnosis of $N$. caninum infection may be associated with poor sample conservation since they usually arrive at the laboratory in the process of autolysis or frozen. These conditions affect the cellular architecture of $N$. caninum and hamper its identification through the immunohistochemistry technique, since it depends on the integrity of parasite morphology and binding of the antigen to the chromogen-labeled antibody (CABRAL et al., 2009).

The main lesions observed in bovine placentas naturally infected by $N$. caninum were inflammation, hemorrhage, and edema. Immunohistochemical analysis confirmed that lesions were caused by the parasite,

\section{Acknowledgment}

To Dr. Andrea Pereira da Costa, for having granted us the anti $-N$. caninum bovine serum and to FAPEMA for the scholarship grant. Dr. Ana Lucia Abreu-Silva is a CNPq Senior Researcher (Grant 309885/2017-5). 


\section{References}

ALMERÍA, S.; LOPEZ-GATIUS, F. Bovine neosporosis: clinical and practical aspects. Research in Veterinary Science, Amsterdam, v. 95, n. 2, p. 303-309, 2013.

BENEVIDES, J.; KATZER, F.; MALEY, S. W.; BARTLEY, P. M.; CANTÓN, G.; PALAREAALBALADEJO, J.; PURSLOW, C. A.; PANG, Y.; ROCCHIL, M. S.; CHIANINI, F.; BUXTON, D.; INNES, E. A. High rate of transplacental infection and transmission of Neospora caninum following experimental challenge of cattle at day 210 of gestation. Veterinary Research, Berlin, v. 43, n. 83, p. 1-13, 2012.

CABRAL, A. D.; CAMARGO, C. N.; BERNARDES, N. T. C. G.; OKUDA, L. H.; PITUCO, E. M.; DEL FAVA, C. Diagnosis of Neospora caninum in bovine fetuses by histology, immunohistochemistry, and nestedPCR. Revista Brasileira de Parasitologia Veterinária, Jaboticabal, v. 18, n. 4, p. 14-19, 2009.

CHIATTONI, C.S. Aspectos atuais do metabolismo do ferro. In: LOPES, A. C. Tratado de clínica médica. 3. ed. Rio de Janeiro: Editora Roca LTDA, 2016. p. 1345-1363.

DUBEY, J. P.; SCHARES, G. Diagnosis of bovine neosporosis. Veterinary Parasitology, Geneva, v. 140, N. 1.-2, p. 1-34, 2006.

DUBEY, J. P.; SCHARES, G. Neosporosis in animalsthe last five years. Veterinary Parasitology, Geneva, v. 180, n. 1, p. 90-108, 2011.

DUBEY, J. P. Review of Neospora caninum and neosporosis in animals. The Korean Journal of Parasitology, Seoul, v. 41, n. 1, p. 1-16, 2003.

GROTTO, H. Z. W. Metabolismo do ferro: uma revisão sobre os principais mecanismos envolvidos em sua homeostase. Revista Brasileira de Hematologia e Hemoterapia, Rio de Janeiro, v. 30, n. 5, p. 390-397, 2008.

GUIMARÃES, M. S. Ciclo silvestre de Neospora caninum e sua importância na epidemiologia para os animais domésticos. 2011. Tese (Doutorado em Ciência Animal) - Universidade Federal de Goiás, Goiânia.

HALLIDAY, J.W.; RAMM, G. A.; POWELL, L. W.; WORWOOD, M. Cellular iron processing and storage: the role of ferritin. In: BROCK, J. H. Iron metabolism in health and disease. London: WB Saunders, 1994, p. 97-121.

KUMAR, V.; ABBAS, A. K.; ASTER, J. C. Robbins patologia básica. 9. ed. Rio de Janeiro: Elsevier, 2013. $928 \mathrm{p}$.

MESQUiTA, L. P.; NOGUEIRA, C. I.; COSTA, R.
C.; ORLANDO, D. R.; BRUHN, F. R.; LOPES, P. F.; NAKAGAKI, K. Y.; PECONICK, A. P.; SEIXAS, J. N.; BEZERRA, P. S. J. R.; RAYMUNDO, D. L.; VARASCHIN, M. S. Antibody kinetics in goats and conceptuses naturally infected with Neospora caninum. Veterinary Parasitology, Geneva, v. 196, n. 3-4, p. 327333, 2013.

MINEO, T. W. Estudo da resposta imune celular e humoral de cães frente à infecção oral por Neospora caninum. 2007. Tese (Doutorado em Medicina Veterinária) Universidade Estadual Paulista, Jaboticabal.

MORAES, L. M. B.; MACEDO, J. R.; GUIMARÃES, A.; SANTOS, H. A.; MACEDO JUNIOR, G. L.; MASSARD, C. L.; MACHADO, R. Z.; BALDANI, C. D. Occurrence of anti-Neospora caninum and antiToxoplasma gondii $\mathrm{IgG}$ antibodies in goats and sheep in western Maranhão, Brazil. Revista Brasileira de Parasitologia Veterinária, Jaboticabal, v. 20, n. 4, p. $312-$ $317,2011$.

NEMATOLLAHI, A.; MOGHADDAM, G. H.; JAAFARI, R.; ASHRAFI, H. J.; NOROUZ, I. M. Study on outbreak of Neospora caninum associated abortion in dairy cows in Tabriz (Northwest Iran) by serological, molecular and histopathologic methods. Asian Pacific Journal of Tropical Medicine, Hainan, v. 6, n. 12, p. 942946, 2013.

PESCADOR, C. A.; CORBELLINI, L. G.; OLIVEIRA, E. C.; RAYMUNDO, D. L.; DRIEMEIER, D. Histopathological and immunohistochemistry aspects of Neospora caninum diagnosis in bovine aborted fetuses. Journal of Veterinary Parasitology, Madrid, v. 150, n. 1-2, p. 159-163, 2007.

PINTO, A. P.; BACHA, F. B.; SANTOS, B. S.; DRIEMEIER, D.; ANTONIASSI, N. A. B.; RIBAS, N. L. K. S.; LEMOS, R. A. A. Sheep abortion associated with Neospora caninum in Mato Grosso do Sul, Brazil. Pesquisa Veterinária Brasileira, Rio de Janeiro, v. 32, n. 8, p. 739-742, 2012.

REICHEL, M. P.; AYANEGUI-ALCÉRRECA, M. A.; GONDIM, L. F.; ELLIS, J. T. What is the global economic impact of Neospora caninum in cattle-the billion-dollar question. International Journal for Parasitology, Oxford, v. 43, n. 2, p. 133-142, 2013.

TEIXEIRA, W. C.; UZÊDA, R. S.; GONDIM, L. F. P.; SILVA, M. I. S.; PEREIRA, H. M.; ALVES, L. C.; FAUSTINO, M. A. G. Prevalência de anticorpos antiNeospora caninum (Apicomplexa: Sarcocystidae) em bovinos leiteiros de propriedades rurais em três microrregiões no estado do Maranhão. Pesquisa Veterinária Brasileira, Rio de Janeiro, v. 30, n. 9, p. 729$734,2010$. 
TOLOSA, E. M. C.; JUNQUEIRA, C.; ARRU, O. fulfillment of the requirements for the degree of Doctor Manual de técnicas para histologia normal e patológica. 2. ed. São Paulo: Manole, 2003, 341 p. of Philosophy in Veterinary Clinical Science, Massey University, Palmerston North, New Zealand. 2011.

WESTON, J. F. Investigations into the control of neosporosis in cattle: a thesis submitted in partial Tese (Doutorado em Filosofia em Ciências Clínicas Veterinárias) - Massey University, Palmerston North. 